Tropical Agricultural Pesearch \& Extension 24 (1): 2021

\title{
ASSESSMENT OF PUBLIC RELATIONS AMONG YAM MARKETERS IN LAGOS STATE, NIGERIA
}

\author{
SA Salau* and SA Omotosho
}

\begin{abstract}
Department of Agricultural Economics and Extension Services, College of Agriculture, Kwara State University, Malete, Nigeria.
\end{abstract}

\begin{abstract}
Public relations (PR) is often overlooked in agricultural marketing and organization. Less priority on PR is usually an indication of poor management that results in inefficient and high labor turnover. This research paper highlights the importance of PR, its determinants in yam marketing and outlines the major challenges hindering the use of PR. A two-stage sampling method was used to select 177 respondents from a total of 299 marketers. Data were collected with the aid of a structured interview schedule. The results revealed that marketers use different PR strategies and the most frequently used PR strategies were phone calls and retailers' association. The market concentration index was developed to determine the structure of yam markets. The value 0.013 , indicates that the yam market was perfectly competitive and non-concentrated. The marketing efficiency is 128.61 percent depicts that the wholesale yam marketers in Lagos state were efficient. The market margin of $22.24 \%$ reveals that every 1 USD sale resulted in a price spread oc 0.22 USD in the wholesale yam marketing. The variables explaining PR strategies are shop size, cost of spoiled yam, the distance of market to the state capital, shop rent and household size. The major challenges hindering the use of $P R$ are a disregard for $P R$ strategies and poor training opportunities. We recommend the use of mobile phone technology and the training of marketers on the use of PR strategies. Weak network and high airtime tariff challenges should be addressed by the government to reduce wastage and mitigate the effects of poor sales on the marketing margin of yam marketers.
\end{abstract}

Keywords: Exchange points, Facebook, Marketing, Market concentration, Market structure, Phone calls, Signage and Wholesalers

\section{INTRODUCTION}

Public relations (PR) can be defined as all kinds of organized communication based on mutual understanding between an organization and its customers to meet desired goals and objectives (Jefkins 2004). PR is one of the typical managerial functions that aid good relationships with customers as well as enhances the positive image of the business or firm (Nyenjeri et al. 2014). PR entails gaining trust among the customers the organization is trying to reach with the aid of certain PR strategies. PR strategy is the strategy marketers use to send the right marketing message to the right customer using the right medium at the right time to get high market shares (Jayne 2019).

\footnotetext{
*Corresponding author: abdulganiyu.shehu@kwasu.edu.ng
}

Marketing and PR have been erroneously perceived as the same, but they are not (Jefkins 2004). Marketing and PR went through drastic growth and evolution during the first half of the twentieth century with increasing influence in the business world (Nyenjeri et al. 2014).. They both use the same technique, target the same publics, expanded their activities and became more vigorous in communicating with larger publics. Marketing involves the recognition of the wants and needs of consumers and the supply of goods and services which satisfy the needs and wants of consumers and the manager at a profit. in essence, PR is all forms of organized communication, between an organization and customers to raise market share (Jayne 2019). 
The entire yam production and marketing chain offers vast employment opportunities to many people. Therefore, a well-developed marketing system is expected to result in efficient marketing of its products. Marketing efficiency involves moving commodities from the place of production to areas they are needed to benefit the producers, marketing intermediaries and consumers (Adetunji et al. 2013). Many agencies participate in marketing activities. These agencies could be facilitators, brokers, transporters, wholesalers and retailers who perform different functions as goods and services move from one point to another. These agencies reduce the number of transactions by creating an assortment and providing varieties of products in one location for customers to buy. According to Coughlan et al. (2001), wholesalers and retailers have improved marketing efficiency tremendously by reducing distribution costs.

Yam is important energy-giving staple food and its marketing offer greater producer surplus for farmers and even more economic surplus through the marketing chain. Unfortunately, the yam producers and marketers do not have a well-organized marketing system in Nigeria. Moreover, the level of application of PR strategies that could command prompt and profitable sales is low among marketers (Salau and Agbede 2020). Consequently, the marketers are characterized by the low standard of living and poverty. Organizations with a lack of PR have been put under fire for poor management, work-life conflict, loss of resources, lack of customers and high labor turnover (Nyenjeri et al. 2014). Furthermore, there are no standard and uniform scale for measuring the size of yam tubers among marketers. This leaves the consumer to their preferences and ability to bargain to secure a good deal. Worst still, most government policies and programs aimed at achieving food security in Nigeria have focused on food production with little regards for food marketing. Worst still, there is a paucity of data on factors influencing PR strategies among agricultural marketers in the literature (Salau and Agbede 2020). Kotler and Mindak (1978) were among the first to address the relationship between public relations and marketing when they outlined five alternative arrangements ie, (1). Separate but equal functions (marketing and public relations have different functions, perspectives and capabilities), (2). Equal but overlapping functions (both are important and separate functions but they share some terrain, particularly product publicity and customer relations; in addition, public relations serves as a 'watchdog' on the social responsibility of marketing), (3). Marketing as the dominant function (marketing manages the relationship with all publics in the same way as the relationship with customers - 'mega marketing'), (4). Public relations as the dominant function (if public relations builds relationships with all i.e. key publics of the organization, then programmes to build relationships with customers, marketing, would be a subset of public relations), and (5). Marketing and public relations as the same function (public relations and marketing converge in concepts and methodologies and a single department manages the external affairs of the company). On the other hand, Hallahan (1999) modified Kotler and Mindak's (1978) typology to include six arrangements: (1) celibate (only one of the functions exists), (2) co-existent (the two functions operate independently), (3) combative (the two functions are at odds), (4) co-optive (one function usurps the other), (5) coordinated (the two functions are independent but work closely together) or (6) combined (the two functions operate within a single unit).

Thus, this study identifies the adopted PR strategies, describes the structure of yam markets, estimate the profitability of yam marketing and determine factors influencing PR strategies used by yam marketers in the study area.

\section{MATERIALS AND METHODS Study Area}

This study was carried out in Lagos State, Nigeria (Figure1). The state is the second populous state next to Kano State with a population of over 21 million people (NPC, 2016) 
The major yam markets in the state are mile 12, Iyana Iba, Oyingbo, Ido, Ebute Elefun, Ajegunle, Mushin, Shibiri and Okokomaiko markets. Yam tubers are normally brought to the state by the Hausas from the northern part of the country such as Sokoto, Kano, Abuja, Kastina, Niger State, etc and the Igbos particularly from Onitsha. The common yam tubers in the area are white yam, water yam, onitsha yam, Abuja yam among others.

\section{Data collection and sampling methods}

Primary data were collected with the aid of a structured interview schedule for information on socio-economic variables, the quantity of yam sold and purchased, public relations strategies employed by the marketers as well as the constraints hindering PR strategies in yam marketing in the area.

The target population for this study was the wholesalers in Lagos state, Nigeria. A twostage sampling technique was used for this study. There are 9 major yam markets in the state and all the main markets were purposively selected in the first stage. The total number of marketers (sampling frame) in each market were known as shown in Table 1.
In the second stage, proportionately, $57 \%$ of the total number of marketers in each market were chosen to give a sample size of 171 respondents.

\section{Analytical techniques}

Descriptive statistics tools such as frequency, percentage, mean, mode and range were used to describe the socio-economic characteristics of the respondents. A 4 point Likert-type scale was used to describe the extent of use of PR strategies adopted by respondents such as the use of phone calls, signage, honoring invitation, retailer association, Whatsapp

\section{Table 1: Selection of respondents}

\begin{tabular}{llll}
\hline $\begin{array}{l}\text { S } \\
\text { I }\end{array}$ & $\begin{array}{l}\text { Main yam } \\
\text { markets }\end{array}$ & $\begin{array}{l}\text { Number of } \\
\text { marketers }\end{array}$ & $\begin{array}{l}\text { Sample } \\
\text { (57\% from } \\
\text { the popula- } \\
\text { tion) }\end{array}$ \\
\hline 1 & Okokomaiko & 30 & 17 \\
2 & Iyana Iba & 22 & 13 \\
3 & Mile 12 & 71 & 41 \\
4 & Shibiri & 11 & 6 \\
5 & Mushin & 38 & 22 \\
6 & Ajegunle & 18 & 10 \\
7 & Ebute Elefun & 34 & 19 \\
8 & Ido & 32 & 18 \\
9 & Oyingbo & 43 & 25 \\
\hline & Total & 299 & 171 \\
\hline
\end{tabular}

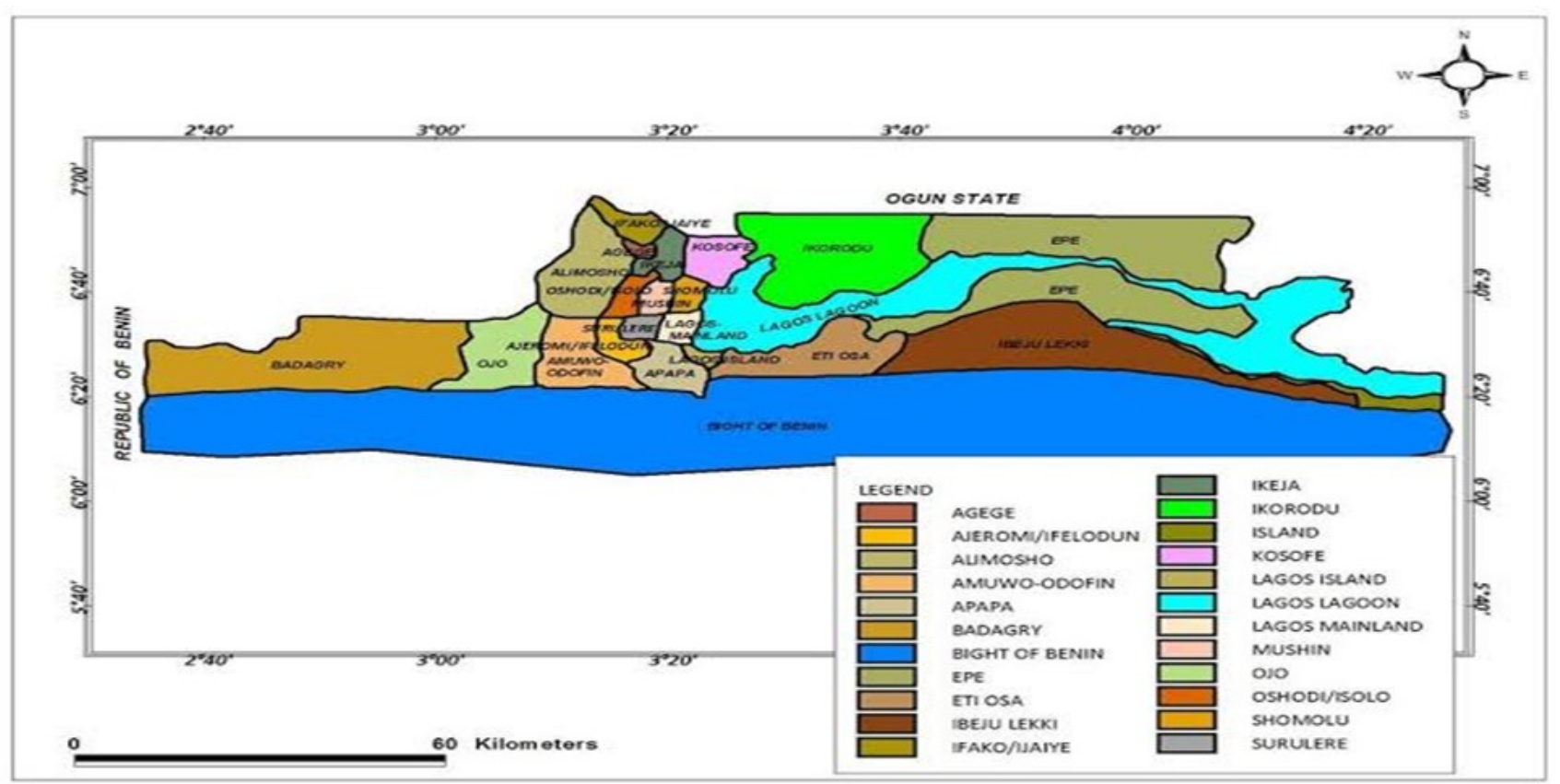

Figure 1: Map of Lagos State showing the various Local Government Areas (LGAs) 
among others. The response options and values assigned were as follows: always $(\mathrm{AW})=4$; sometimes $(\mathrm{ST})=3$; $\operatorname{rarely}(\mathrm{RY})=2$; Never $(\mathrm{NE})=1$.

The market concentration was analyzed using the Herfindahl-Hirschman Index (HI), which has been illustrated by Shehu and Mohammed (2017).

The Index is given as:

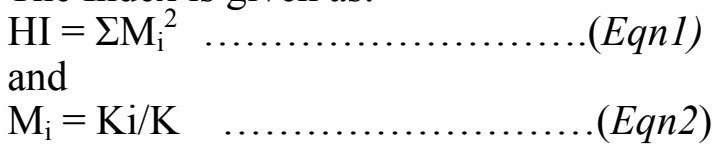

Where;

$\mathrm{Mi}=$ Market share for ${ }_{\mathrm{i}}$ th respondent

$\mathrm{Ki}=$ total tons of yam sold per cycle per respondent

$\mathrm{K}=$ total tons of yam sold per cycle by all respondents

Marketing efficiency (ME) was obtained from the ratio of revenue realized in yam marketing, to the costs of marketing services expressed in percentage (Ozougwu, 2002).

$\mathrm{ME}=\mathrm{ROFM} / \mathrm{COMS} \times 100$ $\operatorname{Eqn}(3)$

Where,

ROFM = revenue obtained from marketing / costs of marketing services

$\mathrm{COMS}=$ costs of marketing services

Marketing margin (MM) (one of the profitability ratios) was employed to determine the profitability of yam marketers (Salau, 2019).

The model is given as:

$$
M M=\frac{C P-S P}{C P} X 100 \ldots \ldots \ldots \ldots(\text { eqn } 4)
$$

Where;

$\mathrm{CP}=$ Consumer or selling price (USD)

$\mathrm{SP}=$ Farm-gate or supply price (USD)
Factors influencing public relations strategies adopted by the respondents were measured using multiple regression analysis. The model is stated as:

$\mathrm{Y}=\mathrm{b}_{0}+\mathrm{b}_{1} \mathrm{X}_{1}+\mathrm{b}_{2} \mathrm{X}_{2}+\mathrm{b}_{3} \mathrm{X}_{3}+\mathrm{b}_{4} \mathrm{X}_{4}+\mathrm{b}_{5} \mathrm{X}_{5}+$ $\mathrm{b}_{6} \mathrm{X}_{6}+\mathrm{b}_{7} \mathrm{X}+\mathrm{b}_{8} \mathrm{X}_{8}+\mathrm{b}_{9} \mathrm{X}_{9}+\mathrm{ei} \ldots \ldots \ldots \ldots($ Eqn5)

Where;

$Y=$ public relations (proxied by the number of PR strategies used by each respondent)

$\mathrm{X}_{1}=$ shop size $\left(\mathrm{m}^{2}\right)$

$\mathrm{X}_{2}=$ education level (number of years spent in school)

$\mathrm{X}_{3}=$ primary occupation (yam marketing $=1$, others $=0$ )

$\mathrm{X}_{4}=$ value of spoilt yam per cycle (USD)

$\mathrm{X}_{5}=$ distance of market to state capital $(\mathrm{km})$

$\mathrm{X}_{6}=$ shop rent (USD)

$\mathrm{X}_{7}=$ distance of market to place of produce

$(\mathrm{km})$

$\mathrm{X}_{8}=$ quantity of yam sold (number of tubers)

$\mathrm{X}_{9}=$ household size (number)

$\mathrm{ei}=$ Error term

b0 $=$ intercept (or constant)

$b_{1}, b_{2} \ldots b_{9}=i$ th coefficient corresponding to

$\mathrm{X}_{1}, \mathrm{X}_{2} \ldots \mathrm{X}_{9}$

To describe the factors hindering PR strategies in the study area, a 5 point Likerttype scale was used. Respondents were asked to indicate whether they agree or disagree and to indicate the extent of agreement or disagreement as the case may be. The response options and values assigned were as follows: strongly disagree (SD) $=5$; disagree $(\mathrm{D})=4$; agree $(\mathrm{A})=3$; moderately agree $(\mathrm{MA})$ $=2$; and strongly agree $(\mathrm{SA})=1$. These values were added and divided by 5 to obtain the mean (3.0). Factors with mean scores greater and lower than 3.0 will be regarded as significant and insignificant factors respectively.

\section{RESULTS AND DISCUSSION}

Socio-economic characteristics of respondents

We observed a majority of the respondents $(57 \%)$ were between the ages of 31-60 with an average age of 46.7 years (Table 02 ).

This suggests that yam marketing is dominated by middle-aged men who are still active, strenuous and can accomplish the 
tedious task of taking yams from the farm gates to the markets. The majority $(86.5 \%)$ of the respondents have access to co-operative societies. Access to credit facilities may affect the quality and quantity of yams traded by the respondents. A large proportion $(72.5 \%)$ of the respondents were literate and $24.5 \%$ were non-literate. Hence, the respondents are supposed to be able to make good decisions which may likely enhance their market shares (Salau and Agbede 2020). The family size ranged between 3 and 13 persons with an average of 9 persons. Their polygamous way of life probably accounts for the large family size recorded in the area. The majority $(88.3 \%)$ of the respondents have yam marketing as their primary occupation while only a few $(13.5 \%)$ of the respondents embraced alternative occupation other than yam marketing as their primary occupation. A considerable percentage of the respondents $(56.8 \%)$ have between $11-20$ years of marketing experience, while only $18.1 \%$ of them have between $21-30$ years of marketing experience with a mean marketing experience of 15 years. This shows that the respondents are experienced in the trade. According to Shehu and Mohammed 2017, this would enable the marketers to understand the intricacies of the trade and thus know how to cut down on marketing costs while attempting to maximize profit.

Table 02: Socio-economic characteristics of the respondents

\begin{tabular}{llll}
\hline Variable & Frequency & Percentage & Mean \\
\hline Age & 39 & 19.5 & \\
$1-30$ & 114 & 57.0 & 46.7 \\
$31-60$ & 47 & 23.5 & \\
$61-90$ & & & \\
\hline Gender & 89 & 52 & \\
Male & 82 & 48 & \\
Female & & & \\
\hline Level of education & 55 & 27.5 & \\
No formal education & 55 & 27.5 & \\
Primary & 67 & 33.5 & \\
Secondary & 23 & 11.5 & \\
Tertiary & & & \\
\hline Marketing experience & 43 & 25.1 & \\
$1-10$ & 97 & 56.8 & \\
$11-20$ & 31 & 18.1 & \\
$21-30$ & & & \\
\hline Household size (number) & 26 & 15.2 & \\
$1-5$ & 104 & 60.8 & \\
6- 10 & 41 & 24.0 & \\
$11-15$ & & & \\
\hline Main source of income & 151 & 88.3 & \\
Yam marketing & 20 & 11.7 & \\
Others & & & \\
\hline Access to Co-operative & 148 & 86.5 & \\
Yes & 23 & 13.5 & \\
No & & & \\
\hline Number of shops & 123 & 71.9 & \\
$1-2$ & 48 & 28.1 & \\
$3-4$ & & & \\
\hline
\end{tabular}

Source: Field survey, 2020 


\section{The extent of use of PR strategies by the respondents}

Table 03 shows the adoption of PR strategies and their importance. Accordingly, mobile phone calls have ranked first as the frequently used PR strategy. These findings agrees with Sikundla et al (2018), who recommended mobile phone as a marketing tool among smallholder irrigation farmers in South Africa. Mobile phone technology is slightly followed by passing messages through retailers associations and the use of signage. The use of Facebook is the least frequently used PR strategy among marketers.

\section{Structure of yam markets}

The Herfindahl index (HI) value of 0.013 was obtained, suggesting a highly competitive and un-concentrated yam marketing industry. The highest value $\mathrm{HI}$ obtainable here is 1 . A very low $(0.013) \mathrm{HI}$ obtained here revealed that the market concentration for yam marketers was very low, thus implying that the market structure tends toward perfect competition, which is characterized by (1) The product sold is homogenous, (2) There is no barrier to entry into the business, (3) There are many buyers and sellers in the study area (Shehu and Mohammed 2017). This result agrees with the findings of Rabirou et al. (201).

\section{Marketing Efficiency of Marketers}

The average total cost and revenue estimated as $\$ 14,233.19$ and $\$ 18,305.59$ respectively
(Table 4). A marketing efficiency value of $128.6 \%$ was obtained, suggesting that yam marketers were slightly efficient in the business.

The profitability of wholesale yam marketing

The market margin is $22.24 \%$, suggesting that every $\$ 1$ sale results in a price spread of

Table 04: Efficiency of wholesale yam marketers

\begin{tabular}{lll}
\hline S/ & Item & USD \\
\hline $\mathbf{N}$ & & \\
\hline 1 & Average cost of truck (50MT) & $12,750.60$ \\
3 & Average cost of transport & $1,149.10$ \\
& $\begin{array}{l}\text { Average cost of warehouse } \\
\text { (shop) }\end{array}$ & 11.62 \\
4 & Average cost of wheelbarrow & 179.49 \\
5 & Average cost of commission & 28.16 \\
6 & Average cost of spoiled yam & 23.79 \\
7 & Average cost of offloading & 67.55 \\
8 & Cost of other marketing ser- & 22.86 \\
& vices & $14,233.19$ \\
9 & Average total cost & $18,305.59$ \\
10 & Average total revenue & $128.61 \%$ \\
11 & Market efficiency & \\
\hline
\end{tabular}

Source: Field Survey, 2020. Note: The official naira to dollar exchange rate was pegged at N390 per \$

Table 03: Extent of adoption of PR strategies

\begin{tabular}{llllllll}
\hline PR strategies & Always & Sometimes & Rarely & Never & mean & SD & Rank \\
\hline Phone calls & $66(38.6)$ & $95(55.6)$ & $8(4.7)$ & $2(1.2)$ & 3.3158 & $0 . .61810$ & $1^{\text {st }}$ \\
Retailers association & $94(55.0)$ & $42(24.5)$ & $30(17.5)$ & $5(2.9)$ & 3.3158 & $0 . .86415$ & $2^{\text {nd }}$ \\
Signage & $109(63.7)$ & $18(10.5)$ & $10(5.8)$ & $34(19.9)$ & 3.1813 & 1.21117 & $3^{\text {rd }}$ \\
Direct supply & $64(37.4)$ & $53(31.0)$ & $38(22.2)$ & $16(9.4)$ & 2.9649 & 0.98754 & $4^{\text {th }}$ \\
Through fellow customer & $49(28.7)$ & $51(29.8)$ & $30(17.5)$ & $41(24.0)$ & 2.6316 & 1.13705 & $5^{\text {th }}$ \\
Honoring invitation & $62(36.3)$ & $33(19.3)$ & $20(11.7)$ & $56(32.7)$ & 2.5906 & 1.27728 & $6^{\text {th }}$ \\
Text message & $42(24.6)$ & $48(28.1)$ & $40(23.4)$ & $41(24.0)$ & 2.5322 & 1.10766 & $7^{\text {th }}$ \\
Whatsapp & $49(28.7)$ & $39(22.8)$ & $32(18.7)$ & $51(29.8)$ & 2.5029 & 1.19496 & $8^{\text {th }}$ \\
Off season visit & $56(32.7)$ & $26(15.2)$ & $28(16.4)$ & $61(35.7)$ & 2.4503 & 1.27493 & $9^{\text {th }}$ \\
Gift & $47(27.5)$ & $39(22.8)$ & $27(15.8)$ & $58(33.9)$ & 2.4386 & 1.21777 & $10^{\text {th }}$ \\
Facebook & $37(21.6)$ & $40(23.4)$ & $31(18.1)$ & $63(36.8)$ & 2.2982 & 1.17771 & $11^{\text {th }}$ \\
\hline
\end{tabular}

Source: Field Survey 2020 NB: the figures in the bracket are the percentage while the ones outside the brackets are the frequencies 
$0.22 \mathrm{k}$ in the wholesale yam marketing (Table 05 ). This indicates that yam marketing is profitable in the study area. Furthermore, since the marketing margin is less than $25 \%$ it shows the retail marketers (buyers) are not being too exploited by the wholesale marketers (Adetunji et al. 2013). This is indicative of the bargaining power of the consumers, as there is the absence of a standard or uniform scale of measurements among yam marketers.

\section{Factors influencing the adoption of PR strategies}

The regression result reveals that the $\mathrm{R}$ square $\left(\mathrm{R}^{2}\right)$ was 0.5805 . This implies that $58.05 \%$ of the total variation in PR strategies employed is explained by the estimated explanatory variables. The remaining $41.95 \%$ not explained is attributed to other variables not included in the model, but present in the error term (Table 06)The regression coefficients of shop size $(\mathrm{t}=-2.025, \mathrm{p}=-0.011)$; cost of spoiled yam $(\mathrm{t}=2.601, \mathrm{p}=0.0101)$; distance of market to state capital $(\mathrm{t}=-2.187, \mathrm{p}=$ $0.0302)$, cost of shop $(\mathrm{t}=2.560, \mathrm{p}=0.0114)$, and household size $(\mathrm{t}=3.829, \mathrm{p}=$ $0.0001)$,were all statistically significant at $5 \%, 5 \%, 5 \%, 5 \%$ and $1 \%$ levels of probability respectively. Other variables such as education, primary occupation, distance and quantity of yam sold have no significant influence on PR strategies used. The positively signed coefficients imply that education, cost of spoiled yam, cost of the shop and household size, have a direct relationship to PR strategies used. On the other hand, shop size, primary occupation, the distance of market to state capital and quantity of yam sold have an indirect relationship to PR strategies used. It implies increasing any of these variables would lead to a decrease in the application of PR strategies.

\section{Challenges hindering the adoption of PR strategies by marketers}

The constraints hindering the adoption of PR strategies in the area are disregard for PR strategies, lack of training opportunities, poor internet facilities, corruption, financial bottleneck, poor power supply, cyber insecurity, high cost and poor funding of PR strategies. The most significant challenge influencing the adoption of PR strategies among marketers is disregard for PR strategies. This was slightly followed by a lack of training opportunities on the effective use of PR strategies and low internet penetration. The least ranked constraint in yam marketing in the area is the high cost of PR strategies.

\section{CONCLUSION}

This study revealed the public relations and marketing strategies practiced by yam

Table 05: Profit calculations of marketers per cycle

\begin{tabular}{lll}
\hline S/N & Item & USD \\
\hline 1 & Average cost of 50 MT of yam & $12,750.60$ \\
2 & Average cost of transport & $1,149.10$ \\
3 & Average cost of warehouse(shop) & 11.62 \\
4 & Average cost of wheelbarrow & 179.49 \\
5 & Average cost of commission & 28.16 \\
6 & Average cost of spoiled yam & 23.79 \\
7 & Average cost of offloading & 67.55 \\
8 & Average cost of other marketing services & 22.86 \\
9 & Average Total cost & $14,233.19$ \\
10 & Average revenue generated & $18,305.59$ \\
11 & Profit (net revenue or net income - total cost) & $4,072.40$ \\
12 & Return per capital invested & 0.28 \\
13 & Percentage Marketing margin (SP-CP/CP multiply by 100) & $22.24 \%$ \\
\hline
\end{tabular}

Source: Field Survey, 2020 
Table 6: Factors influencing PR strategies adopted by marketers

\begin{tabular}{lccl}
\hline Variables & Coefficient & t-statistics & p-value \\
\hline Constant & 8.56982 & 6.080 & $0.00001 * * *$ \\
Shop size & -0.02048 & -2.025 & $0.04453 * *$ \\
Education & 0.00555 & 0.124 & 0.90120 \\
Major occupation & -0.49876 & -1.563 & 0.12013 \\
Cost of spoiled yam & $3.47462 \mathrm{E}-05$ & 2.601 & $0.01019 * *$ \\
Distance to state capital & -0.01293 & -2.187 & $0.03021 * *$ \\
Shop rent & 0.00016 & 2.560 & $0.01140 * *$ \\
Distance to exchange point & -0.00016 & -0.348 & 0.72864 \\
Quantity of yam sold & -0.71887 & -0.694 & -0.694 \\
Household size & 0.14664 & 3.829 & $0.00019 * * *$ \\
\hline
\end{tabular}

$*, * *,{ }^{* * *}$ Significant at $10 \%, 5 \%$ and $1 \%$ respectively. $\mathrm{R}^{2}=0.5805$

marketers in Lagos State, Nigeria. The public relations strategies used by the marketers are; phone calls to customers to attract sales, visiting the retailers association, signage, direct supply and honoring customers' invitation. Furthermore, the Herfindahl index indicated that the yam market is nonconcentrated and a perfectly competitive one. This implies that the structure of yam markets is such that there is a large number of sellers and buyers and there are no barriers to entry. In addition, the calculated marketing efficiency and margin revealed that yam marketing is efficient and profitable. Shop size, cost of spoiled yam, and distance of market to the state capital, cost of the shop and household size are the significant variables explaining PR strategies adopted by marketers in the area. The major challenges hindering the use of public relations in yam marketing were disregarding PR strategies and poor training opportunities for marketers. The marketers should be well trained through their marketing association on the effective use of PR strategies. They should also be enlightened on the important roles PR strategies play in marketing. We recommend mobile phones as a marketing tool among marketers. The government should address erratic network and high airtime tariff challenges to encourage mobile phone adoption in agricultural marketing in the country. The government should also pay attention to the pricing and measurement in the industry while discouraging larger shop size.

\section{Author Contribution}

SAS conceptualized and designed the study. SAO performed the experiments. SAO analyzed and interpret the data. SAO contributed in drafting the manuscript and SAS critically revised the manuscript.

\section{REFERENCES}

Adetunji MO, Oladejo JA, and Ojedokun IK 2013 "Market and marketing of agricultural produce". 2nd Ed., Johnny printing works, Ogbomosho, Nigeria: 40-61.

Coughlan AT, Anderson E, Stern LW, and Ansary AI 2001 Marketing channels, $7^{\text {th }}$ Ed, Prentice Hall, New Jersey, United States

Hallahan K 1999 Seven models of framing: Implications for public relations. Journal of Public Relations Research, 11(3), 205-242.

Jayne T. 2019 Marketing Communication tips, bizfluent, https://bizfluent.com/ how-7424569-different-methodsmarketing-communication.html, Retrieved March 04, 2019.

Jefkins B 2004 Public Relations Contemporary Issues and Techniques. 2nd Ed. Butterworth- Heinemann, Oxford, United Kingdom

Kotler P and Mindak W 1978 Marketing and public relations: should they be 
partners or rivals. Journal of Marketing 42(10): 13-20.

National Population Commission (NPC) 2016 Federal Republic of Nigeria Official Gazette, 96(2): 1-10.

Nyenjeri JK, Kinyua F \& Wawire N 2014 The Effects of Public Relations in Delivery of Forestry Services at Kenya Forest Service Headquarters. European Journal of Business Management, 1 (11), 217-230.

Ozougwu FC 2002 Analysis of Rice Marketing Margin in the Marketing Channel of Adani Rice in UzoUwani Local Government Area. MSc Thesis, University of Nigeria Nsukka. $158 \mathrm{pp}$.

Rabirou K, Abdulhameed AG \& Ismaila DS 2018 Analysis of Yam Marketing in Akoko North- East Local Government Area of Ondo State, Nigeria. International Journal of Agricultural Marketing, 5(1): 170-177.

Shehu AS \& Mohammed AS 2017 Economic Analysis of Tomato Marketing in Ilorin Metropolis, Kwara State, Nigeria Journal of Agricultural Sciences, 62(2): 179-191.

Salau SA and Agbede TB 2020. An assessment of public relations among certified and non- certified cocoa marketers in Ondo state, Nigeria. Electronic Journal of Polish Agricultural Universities (EJPAU) 23(4): 1-7.

Salau SA 2019 Analysis of Discount Pricing and its Determinants among Cocoa Marketers in Ondo state, Nigeria FUOYE Journal of Agriculture and Human Ecology 3(1): 30-37.
Sikundla T, Mushunje A and Akinyemi BE 2018 Socioeconomic drivers of mobile phone adoption for marketing among smallholder irrigation farmers in South Africa Journal of Cogent Social Sciences, 4: 1-12. 